\title{
Molecular Genetics of Kawasaki Disease
}

\author{
YOSHIHIRO ONOUCHI
}

\author{
Laboratory for Cardiovascular Diseases, Center for Genomic Medicine, RIKEN, Yokohama, Kanagawa 230-0045, Japan
}

\begin{abstract}
Kawasaki disease (KD) is a leading cause of acquired cardiac disease of children in the developed countries. The pathogen that triggers this perplexing disease is still unknown after $40 \mathrm{y}$ from the first description. Epidemiologic findings have made us believe that there are considerable genetic components in the etiology and some candidate genetic variations, which confer susceptibility to KD or risk for coronary artery lesions have been identified. However, most of them remain to be definitively confirmed by replication studies with large cohorts. In this article, I review the candidate gene association studies to date. I also introduce our recent findings in genome-wide approach, which revealed the importance of $\mathrm{Ca}^{2+}$ / nuclear factor of activated T-cells pathway in the pathogenesis of KD.

(Pediatr Res 65: 46R-54R, 2009)
\end{abstract}

$\mathrm{K}^{\mathrm{a}}$ awasaki disease (KD) is a systemic vasculitis syndrome which preferentially affects infants and children $(1,2)$. Past large epidemics in Japan, peaked incidence at 9-11 mo of age, which coincides with waning of maternal immunity and symptoms partly similar to other infectious disorders suggest that some microorganisms may trigger the disease. However, despite large efforts, the cause of this mysterious disease still remains unknown. Contrary to their initial expectation of a benign illness, coronary artery lesions (CALs) developed in $15-25 \%$ of untreated patients has made KD a leading cause of acquired heart disease of children in the developed countries (3). Intravenous gamma globulin (IVIG) therapy dramatically reduced occurrence of CALs, however, about $15 \%$ of the patients poorly respond to the treatment and are at higher risk for CALs. Following epidemiologic findings have suggested that genetic predisposition might underlie the etiology of KD. First, KD is much common in East Asian countries. In Japan, incidence of $\mathrm{KD}$ is continuously increasing and in recent years, more than 180 per 100,000 children younger than 4 y are affected annually (4).

The incidence is 10-20 times higher than that of Western countries. The same level of incidence in Japanese ancestries living in Hawaii (5) is indicating that the predilection for oriental populations might not be due to geographical reasons. Second, KD has familial accumulation. Relative risk for sibs $(\lambda \mathrm{s})$ is about 10 and recent study revealed that two-generation KD patients exist more than expected $(6,7)$. Thus, KD can be considered as a complex multifactorial disease (Fig. 1). Identification of genetic factors related to individual susceptibility or different incidence among ethnicity might provide a clue to

Received October 31, 2008; accepted November 26, 2008

Correspondence: Yoshihiro Onouchi, M.D., Ph.D., Laboratory for Cardiovascular Diseases, Center for Genomic Medicine, RIKEN, 1-7-22, Suehiro, Tsurumi, Yokohama, Kanagawa 230-0045, Japan; e-mail: onouchi@src.riken.jp

This work was supported by grants from the Japanese Millennium Project and from the Japan Society for the Promotion of Science (16591069 Y.O.). unravel the enigma of KD. Recent advances in molecular genetics have greatly accelerated identification of susceptibility genes for complex diseases. Currently, there are two mainstreams of strategy for identification of disease genes. One is candidate gene approach and the other is genome-wide approach.

\section{Candidate Gene Approach}

Most genetic studies of KD have focused on candidate genes. This approach is derived from "functional cloning" used in searching for genes responsible for monogenic disorders. Genes for analyses were selected based on the information of their known function or role in the disease pathophysiology. ${ }^{1}$

\section{HLA}

Human leukocyte antigens (HLA) are located on the chromosome $6 \mathrm{p} 21.3$ region and their polymorphisms are associated with various diseases directly or indirectly as a consequence of linkage disequilibrium (LD) between polymorphisms of other neighboring genes. There are large differences in distribution of HLA alleles among races or ethnicity. Initial genetic studies of KD were focused on HLA class I antigens. Matsuda et al. (8) and Kato et al. (9) reported that Japanese specific variant of HLA-Bw22 (now called as Bw54) was predominant in Japanese KD patients. In the studies of white $(10,11)$ and Jewish population $(12)$, association between HLA-Bw51 and KD was found. However, neither trend of association was replicated in the Southern Chinese population (13) and in the Korean population (14). One of the reasons that KD has been regarded as infectiontriggered disorder is past epidemic in Japan and in the United States. HLA-B44 was predominant in the epidemic KD cases in Boston (11). This finding was supported by the report by Kaslow et al. (15) in which HLA-A2, B44 and Cw5 antigen combination was associated with KD patients involved in an outbreak in Maryland. On the other hand, Harada et al. (16) analyzed sharing of HLA-A-B-C-DR haplotypes between 23 affected sib pairs of Japanese KD patients and failed to find evidence of association. Several groups have studied relationship between KD and HLA class II antigens, however, no significant association has been observed until now (17-19).

Abbreviations: ASP, affected sibpair; CALs, coronary artery lesions; IP3, inositol 1,4,5-trisphosphate; ITPKC, inositol 1,4,5-trisphosphate 3-kinase C; IVIG, intravenous gamma globulin; KD, Kawasaki disease; LD, linkage disequilibrium; MMP, matrix metalloproteinase; NFAT, nuclear factor of activated T cells; SNPs, single nucleotide polymorphisms; TIMPs, tissue inhibitors of metalloproteinases 
Thus, a single allele or haplotype of HLA that confers KD susceptibility has not been identified yet. Previous studies about association between HLA and KD were summarized in Table 1. Considering that no evidence of linkage was observed near $6 p$ region in the genome-wide affected sib-pair (ASP) study of KD (20), the involvement of HLA in KD pathogenesis might be limited or more complex than expected.

\section{Non-HLA Genes}

Tumor necrosis factor- $\alpha$ (TNF- $\alpha$ ) is a proinflammatory cytokine mainly produced by macrophages. The possible involvement of this cytokine in vascular damage and elevated serum level in the acute phase KD patients who developed CALs suggests its key role in the disease pathogenesis $(21,22)$. Recent case series suggesting successful treatment using MAb against TNF- $\alpha$ (infliximab) on IVIG resistant patients (23-25) back up this idea. Association of single nucleotide polymorphisms (SNPs) that may alter TNF- $\alpha$ expression with various inflammatory diseases has been extensively studied. Kamizono et al. (26) conducted association study about five SNPs $(-1031 \mathrm{~T}>\mathrm{C},-863 \mathrm{C}>\mathrm{A},-857$ $\mathrm{C}>\mathrm{T},-308 \mathrm{G}>\mathrm{A}$ and $-238 \mathrm{G}>\mathrm{A}$ ) located at $5^{\prime}$ flanking region of $T N F-\alpha$ gene in the Japanese population. In this

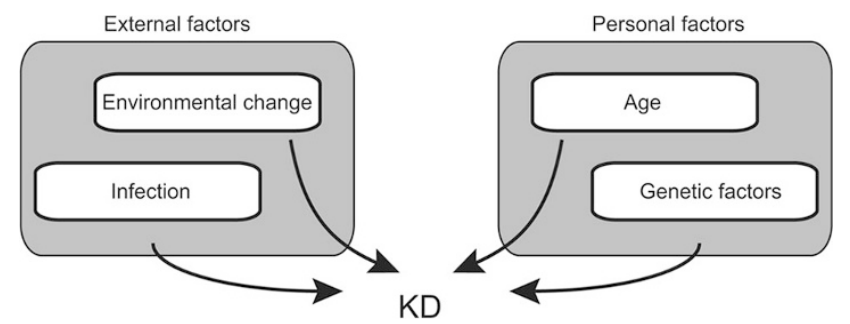

Figure 1. Multiple factors that could be linked to Kawasaki disease. study, no association was observed between these polymorphisms and KD occurrence or CALs formation. Quasney et al. (27) investigated the distribution of $+250 \mathrm{~A}>\mathrm{G}$ of lymphotoxin- $\alpha$ gene in addition to $-308 \mathrm{G}>\mathrm{A}$ of $T N F-\alpha$ and found positive association of $T N F-\alpha-308 \mathrm{~A} / \mathrm{G}$ genotype with CALs in white KD patients. Chien et al. (28) and Ahn et al. (29) reported negative association between polymorphisms in $T N F-\alpha$ gene and susceptibility to KD or CALs in the Taiwanese and the Korean populations, respectively. In a recent report by Cheung et al. (30), TNF- $\alpha-308$ A allele was associated with $\mathrm{KD}$ in the Chinese population. Cheung also showed that this SNP was associated with intima-media thickness of carotid arteries.

Burns et al. (31) applied family-based association study to KD for the first time. Ninety-five SNPs in 58 candidate genes for cardiovascular diseases and inflammation were selected and their transmission patterns in 269 trios of KD patients and their parents were investigated. They found a SNP in the promoter region of interleukin (IL)-4 gene was asymmetrically transmitted. $I L-4$ is located in the cytokine gene cluster on $5 \mathrm{q} 31$ region where positive linkage signal was observed in a sib-pair linkage study of KD (20). However, replication study performed by two Taiwanese groups failed to validate the finding $(32,33)$. IL-4 is known to promote differentiation of naive T cells into Th2 cells. Elevated serum IL-4 in the acute phase of KD was reported, and many aspects of immune response in KD pathophysiology are associated with $\mathrm{Th} 2$ reaction, hence the cytokine could play a role in the pathogenesis of KD. Further investigation is needed to understand the involvement of the SNPs of $I L-4$ gene in individual susceptibility to KD. Association studies focused on SNPs or copy number variations of genes for other cytokines, as well as chemokines and their receptors have also been conducted (32,34-40; Table 2).

Table 1. Association studies between HLA and KD

\begin{tabular}{|c|c|c|c|}
\hline Haplotypes & Number of samples (cases/controls) & Ethnicity & References \\
\hline \multicolumn{4}{|l|}{ Reports of positive association } \\
\hline $\mathrm{Bw} 22 \mathrm{~J}$ & $32 / 76$ & Japanese & 8 \\
\hline Bw22J2 & $205 / 500$ & Japanese & 9 \\
\hline \multicolumn{4}{|l|}{ Bw15 } \\
\hline Bw51 & $23 / 244$ & White American & 10 \\
\hline Bw51 & $12 / 90$ & Jewish & 12 \\
\hline Bw44 (epidemic cases)* & $23 / 246$ & White American & 11 \\
\hline Bw44 (epidemic cases) & $16 / 608$ & White American & 15 \\
\hline DRB3*0301† & $21 / 200$ & White American & 17 \\
\hline B35 & $74 / 159$ & Korean & 14 \\
\hline \multicolumn{4}{|l|}{ B37 } \\
\hline \multicolumn{4}{|c|}{ Cw09 } \\
\hline \multicolumn{4}{|c|}{ Reports of negative association } \\
\hline \multicolumn{4}{|c|}{ Loci (number of haplotypes tested) } \\
\hline HLA-A (10) & $62 / 100$ & Chinese & 13 \\
\hline \multicolumn{4}{|l|}{ HLA-B (15) } \\
\hline \multicolumn{4}{|l|}{ HLA-DR (11) } \\
\hline DRB1 (41) & $25 / 209$ & White American & 17 \\
\hline \multicolumn{4}{|l|}{ DQA1 (7) } \\
\hline \multicolumn{4}{|l|}{ DQB1 (13) } \\
\hline \multicolumn{4}{|l|}{ DPB1 (17) } \\
\hline DRB1 (35) & $145 / 331$ & Taiwanese & 18 \\
\hline
\end{tabular}

*Association was not significant after correction of multiple comparison.

$†$ Association was not confirmed in the authors' subsequent study in the other area of the United States. 
Table 2. Candidate genes previously tested for association with KD

\begin{tabular}{|c|c|c|c|c|}
\hline Symbol* & Gene & Region & Phenotype & References \\
\hline MTHFR & $\begin{array}{l}\text { 5,10-methylenetetrahydrofolate } \\
\text { reductase }\end{array}$ & $1 \mathrm{p} 36.3$ & CAL formation & $61 \dagger$ \\
\hline \multirow[t]{3}{*}{$C R P$} & C-reactive protein & $1 \mathrm{q} 21-\mathrm{q} 23$ & $\mathrm{KD}$ & 30 \\
\hline & & & CAL formation & $30 \ddagger$ \\
\hline & & & Intima-media thickness§ & 30 \\
\hline \multirow[t]{3}{*}{$I L-10$} & Interleukin 10 & $1 \mathrm{q} 31-\mathrm{q} 32$ & $\mathrm{KD}$ & $37 \ddagger$ \\
\hline & & & CAL formation & 37 \\
\hline & & & Serum albumin level & 37 \\
\hline \multirow[t]{2}{*}{$F C G R 2 A$} & $\begin{array}{l}\mathrm{Fc} \text { fragment of IgG, low affinity IIa, } \\
\text { receptor }(\mathrm{CD} 32)\end{array}$ & $1 \mathrm{q} 23$ & $\mathrm{KD}$ & $62 \ddagger, 63 \ddagger$ \\
\hline & & & CAL formation & $62,63+$ \\
\hline \multirow[t]{2}{*}{$F C G R 2 B$} & $\begin{array}{l}\text { Fc fragment of } \mathrm{IgG} \text {, low affinity } \mathrm{IIb}, \\
\text { receptor }(\mathrm{CD} 32)\end{array}$ & $1 \mathrm{q} 23$ & $\mathrm{KD}$ & $63 \div$ \\
\hline & & & CAL formation & $63 \ddagger$ \\
\hline \multirow[t]{2}{*}{ FCGR3A } & $\begin{array}{l}\text { Fc fragment of } \mathrm{IgG} \text {, low affinity IIIa, } \\
\text { receptor }(\mathrm{CD} 16 \mathrm{a})\end{array}$ & $1 \mathrm{q} 23$ & $\mathrm{KD}$ & 62,63 \\
\hline & & & CAL formation & $62 \ddagger, 63 \ddagger$ \\
\hline \multirow[t]{2}{*}{$F C G R 3 B$} & $\begin{array}{l}\mathrm{Fc} \text { fragment of } \mathrm{IgG} \text {, low affinity } \mathrm{IIIb}, \\
\text { receptor }(\mathrm{CD} 16 \mathrm{~b})\end{array}$ & $1 \mathrm{q} 23$ & $\mathrm{KD}$ & $62 \ddagger, 63 \ddagger$ \\
\hline & & & CAL formation & $62 \ddagger, 63 \ddagger$ \\
\hline$I L-1 \beta$ & Interleukin 1 , beta & $2 q 14$ & $\mathrm{KD}$ & $32 \ddagger$ \\
\hline$I L-1 R a$ & Interleukin 1 receptor antagonist & $2 \mathrm{q} 14.2$ & $\mathrm{KD}$ & 32 \\
\hline CXCR2 & Chemokine (C-X-C motif) receptor 2 & $2 \mathrm{q} 35$ & $\mathrm{KD}$ & $40 \ddagger$ \\
\hline CXCR1 & Chemokine (C-X-C motif) receptor 1 & $2 \mathrm{q} 35$ & $\mathrm{KD}$ & $40 \ddagger$ \\
\hline SLC11A1 & Solute carrier family 11 & $2 \mathrm{q} 35$ & $\mathrm{KD}$ & 60 \\
\hline UGT1A1 & $\begin{array}{l}\text { UDP glucuronosyltransferase } 1 \\
\text { family, polypeptide A1 }\end{array}$ & $2 \mathrm{q} 37$ & $\mathrm{KD}$ & $64 \ddagger$ \\
\hline CX3CR1 & Chemokine (C-X3-C motif) receptor 1 & $3 \mathrm{p} 21.3$ & $\mathrm{KD}$ & $40 \ddagger$ \\
\hline CCR3 & Chemokine $(\mathrm{C}-\mathrm{C})$ receptor 3 & $3 \mathrm{p} 21$ & $\mathrm{KD}$ & 40 \\
\hline$C C R 2$ & Chemokine $(\mathrm{C}-\mathrm{C})$ receptor 2 & $3 \mathrm{p} 21$ & $\mathrm{KD}$ & 40 \\
\hline \multirow[t]{2}{*}{ CCR5 } & Chemokine $(\mathrm{C}-\mathrm{C})$ receptor 5 & $3 \mathrm{p} 21$ & $\mathrm{KD}$ & $35,39,40$ \\
\hline & & & CAL formation & $39 \ddagger$ \\
\hline \multirow[t]{2}{*}{ AGTR1 } & Angiotensin II receptor, type 1 & $3 q 21-q 25$ & KD & $50 \ddagger$ \\
\hline & & & Coronary stenosis & 50 \\
\hline \multirow[t]{2}{*}{ VEGFR2 } & $\begin{array}{l}\text { Vascular endothelial growth factor } \\
\text { receptor } 2\end{array}$ & $4 q 12$ & $\mathrm{KD}$ & $43 \ddagger$ \\
\hline & & & CAL formation & 43 \\
\hline \multirow[t]{2}{*}{$I L-4$} & Interleukin 4 & $5 q 31.1$ & $\mathrm{KD}$ & $31,32 \ddagger, 33 \ddagger$ \\
\hline & & & CAL formation & $31 \ddagger, 33 \ddagger$ \\
\hline \multirow[t]{2}{*}{$C D 14$} & CD14 antigen & $5 q 31.1$ & $\mathrm{KD}$ & $56 \ddagger$ \\
\hline & & & CAL formation & 56 \\
\hline \multirow[t]{2}{*}{$V E G F A$} & Vascular endothelial growth factor A & $6 \mathrm{p} 12$ & KD & $43 \ddagger, 44,45,46 \ddagger$ \\
\hline & & & CAL formation & $43,45 \ddagger, 46 \ddagger$ \\
\hline$M I C A$ & $\begin{array}{l}\text { MHC class I polypeptide-related } \\
\text { sequence A }\end{array}$ & $6 \mathrm{p} 21.3$ & CAL formation & 65 \\
\hline \multirow{2}{*}{$L T A$} & Lymphotoxin alpha & $6 \mathrm{p} 21.3$ & $\mathrm{KD}$ & 27 \\
\hline & & & CAL formation & $27 \ddagger$ \\
\hline \multirow[t]{3}{*}{$T N F-\alpha$} & Tumor necrosis factor- $\alpha$ & $6 \mathrm{p} 21.3$ & KD & $26 \ddagger, 27 \ddagger, 29 \ddagger, 28 \ddagger, 30$ \\
\hline & & & CAL formation & $27,30 \ddagger$ \\
\hline & & & Arterial stiffness $\|$ & 30 \\
\hline \multirow[t]{3}{*}{ PAFAH } & $\begin{array}{l}\text { Platelet-activating factor } \\
\text { acetylhydrolase }\end{array}$ & $6 \mathrm{p} 21.2-\mathrm{p} 12$ & $\mathrm{KD}$ & $66 \ddagger$ \\
\hline & & & CAL formation & $66 \ddagger$ \\
\hline & & & IVIG unresponsiveness & 66 \\
\hline$I L-6$ & Interleukin 6 & $7 \mathrm{p} 21$ & $\mathrm{KD}$ & $36 \ddagger$ \\
\hline \multirow[t]{2}{*}{ eNOS } & Endothelial nitric oxidase synthase & $7 \mathrm{q} 36$ & $\mathrm{KD}$ & $67 \ddagger$ \\
\hline & & & CAL formation & $67 \ddagger$ \\
\hline \multirow[t]{3}{*}{$M B L$} & Mannose-binding lectin & $10 \mathrm{q} 11.2-\mathrm{q} 21$ & KD & $57,59+$ \\
\hline & & & CAL formation & 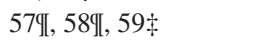 \\
\hline & & & Arterial stiffness $\|$ & 59 \\
\hline \multirow[t]{2}{*}{ IL-18 } & Interleukin 18 & $11 \mathrm{q} 22.2-\mathrm{q} 22.3$ & KD & 38 \\
\hline & & & CAL formation & $38 \ddagger$ \\
\hline \multirow{2}{*}{$M M P 3$} & Matrix metallopeptidase 3 & $11 \mathrm{q} 22.3$ & $\mathrm{KD}$ & $53 \ddagger, 54 \ddagger, 55 \ddagger$ \\
\hline & & & CAL formation & $\begin{array}{l}53,54 \ddagger, 55 \ddagger \\
(\text { Continued })\end{array}$ \\
\hline
\end{tabular}


Table 2. (Continued)

\begin{tabular}{|c|c|c|c|c|}
\hline Symbol* & Gene & Region & Phenotype & References \\
\hline \multirow[t]{2}{*}{$M M P 12$} & Matrix metallopeptidase 12 & $11 \mathrm{q} 22.3$ & KD & $54 \ddagger$ \\
\hline & & & CAL formation & $54 \ddagger$ \\
\hline \multirow[t]{2}{*}{$M M P 13$} & Matrix metallopeptidase 13 & $11 \mathrm{q} 22.3$ & $\mathrm{KD}$ & $54 \div$ \\
\hline & & & CAL formation & 54 \\
\hline \multirow[t]{2}{*}{$M M P 2$} & Matrix metallopeptidase 2 & $16 q 13-q 21$ & $\mathrm{KD}$ & $54 \ddagger$ \\
\hline & & & CAL formation & $54 \div$ \\
\hline \multirow[t]{2}{*}{ iNOS } & Nitric oxide synthase 2 , inducible & $17 q 11.2-q 12$ & $\mathrm{KD}$ & $67 \ddagger$ \\
\hline & & & CAL formation & $67 \ddagger$ \\
\hline$M C P 1$ & Monocyte chemoattractant protein-1 & $17 q 11.2-q 12$ & $\mathrm{KD}$ & $34 \ddagger$ \\
\hline CCL3L1 & Chemokine (C-C motif) ligand 3-like 1 & $17 \mathrm{q} 11.2$ & KD & 35 \\
\hline \multirow[t]{3}{*}{$A C E$} & Angiotensin I converting enzyme & $17 \mathrm{q} 23$ & $\mathrm{KD}$ & $48,49,50 \ddagger$ \\
\hline & & & CAL formation & $47,48 \div, 49 \ddagger$ \\
\hline & & & Coronary stenosis & 50 \\
\hline \multirow[t]{2}{*}{$T I M P 2$} & Tissue inhibitor of metalloproteinase 2 & $17 q 25$ & $\mathrm{KD}$ & $52 \ddagger$ \\
\hline & & & CAL formation & 52 \\
\hline \multirow[t]{2}{*}{$M M P 9$} & Matrix metallopeptidase 9 & $20 q 11.2-q 13$ & $\mathrm{KD}$ & $53 \ddagger, 54 \ddagger$ \\
\hline & & & CAL formation & $53 \ddagger, 54 \neq$ \\
\hline HMOX1 & Heme oxygenase (decycling) 1 & $22 q 12$ & $\mathrm{KD}$ & $64 \div$ \\
\hline \multirow[t]{2}{*}{$C D 40 L$} & CD40 ligand & $\mathrm{Xq} 26$ & $\mathrm{KD}$ & $68 \ddagger, 69 \ddagger$ \\
\hline & & & CAL formation & $68 * *, 69 \ddagger$ \\
\hline
\end{tabular}

*When several gene symbols were available, those used in the references were selected.

$†$ Association only in female patients.

\$Reports of negative association results.

§Intima-media thickness of right common carotid artery was measured.

\|Stiffness of brachioradial artery and carotid artery was measured in reference 59 and 30, respectively.

IIAssociation in KD patients younger than $1 \mathrm{y}$.

**Association only in male patients.

Genes related to vasoactive or angiogenic molecules also can be considered as candidates for KD susceptibility or severity. Vascular endothelial growth factor (VEGF) is expressed in various types of cells including leukocytes and vascular smooth muscle cells. Binding of VEGF to its receptor (VEGFR-1 and VEGFR-2) expressed on endothelial cells induces cell proliferation, survival, migration, and angiogenesis. Its ability to induce vascular hyperpermeability and chemotaxis of bone marrow-derived cells suggest significant roles of VEGF in inflammation (41). VEGF is up-regulated in the acute phase of KD and the serum level of this protein is associated with formation of CALs in one study (42). Kariyazono et al. (43) reported a SNP in the 5' untranslated region (UTR) of VEGF (rs2010963) was associated with CALs in the Japanese population. In the study of Dutch KD patients, 2 SNPs other than rs2010963 showed association with KD (44). With regard to association of rs2010963 with KD or CALs, two inconsistent results were also reported by Taiwanese groups $(45,46)$.

Association of the insertion/deletion (I/D) polymorphism of a gene for angiotensin I converting enzyme with cardiovascular diseases and hypertension has been extensively examined. This polymorphism is located in intron 16 and is in strong LD with other SNPs in the $5^{\prime}$ and $3^{\prime}$ regions of the gene. Takeuchi et al. (47) reported association of I/I genotype with CALs in the Japanese. Taiwanese and Korean groups reported I allele or I/I genotype was associated with KD susceptibility but not with risk for CALs $(48,49)$. Fukazawa $e t$ al. (50) reported that the $\mathrm{D}$ allele in concert with the $\mathrm{C}$ allele of the SNP in the 3' UTR (+1166 A/C) of angiotensin II type
I receptor gene increased risk for coronary artery stenosis in another Japanese cohort.

Matrix metalloproteinases (MMPs), produced by a variety of cell types, play important roles in various physiologic and pathologic processes by degrading extracellular matrices. The activity of MMPs is controlled by their endogenous inhibitor, the tissue inhibitors of metalloproteinases (TIMPs). Imbalances between MMPs and TIMPs are related to pathologic conditions such as arthritis, tumor metastasis, and aortic aneurysms. MMPs and TIMPs are elevated in the serum or vascular tissue of acute KD patients and association of increased MMP9/TIMP2 and MMP3/TIMP1 ratios with risk for CALs formation was reported (51). Furuno et al. (52) identified that promoter polymorphisms of TIMP2 gene was associated with increased risk of CALs. 6A allele of an insertion/ deletion polymorphism $(5 \mathrm{~A} / 6 \mathrm{~A})$ of $M M P-3$ gene promoter was more predominant in the Korean KD patients with $\mathrm{CAL}$ (53). Although not significant, the 5A allele showed a trend of association with CALs in the Japanese population (54). Another promoter SNP of MMP-3 was not associated with KD or CALs in the Korean population (55). Ikeda et al. (54) conducted association study of five functional polymorphisms of $M M P-2,3,9,12$, and 13 genes and observed significant association between a promoter SNP or a haplotype of MMP-13 and CALs.

There has been growing interest in involvement of innate immune system in the pathophysiology of inflammatory diseases. Genes for pattern recognition receptors (PRRs) which recognize pathogen-associated molecular patterns and downstream signaling peptides which cause cytokine production 
through activating nuclear factor kappa-B (NF-kB) and/or caspase-1 have become an active area of genetic research. As for KD, positive association of the SNPs in the promoter of $C D 14$, a PRR for LPS expressed on monocytes/macrophages and neutrophils with CALs was reported (56). Mannose binding lectin (MBL) and C-reactive protein (CRP), known as acute phase proteins produced in liver, also have roles in innate immune reaction. MBL can initiate complement activation directly by binding to mannose and N-acetyl glucosamine residues on the surface of microorganisms. Ligands of CRP are phosphocholine on microorganisms or damaged cell membranes. CRP also initiates complement activation by binding to C1q. Association between functional polymorphisms of $M B L$ gene and CALs in KD patients younger than 1 y was described $(57,58)$. Cheung et al. $(30,59)$ reported that polymorphisms in $M B L$ and $C R P$ were associated with arterial stiffness or intima-media thickness. Ouchi et al. (60) reported association between a GT repeat polymorphism in 5' region of solute carrier family 11 (proton-coupled divalent metal ion transporters), member 1 (SLC11A1) gene, and KD. SLC11A1 is a divalent cation $\left(\mathrm{Fe}^{2+}, \mathrm{Zn}^{2+}\right.$, and $\left.\mathrm{Mn}^{2+}\right)$ transporter on the endosomes and regulates macrophage activation. Association of polymorphisms in genes for 5,10-methylenetetrahydrofolate reductase (61), Fc gamma receptors $(62,63)$, UDP glucuronosyltransferase (64), heme oxygenase (64), MHC class I polypeptide-related sequence A (65), platelet-activating factor acetylhydrolase (66), NO syntheses (67), and CD40 ligand $(68,69)$ with KD or phenotypes related to KD have also been studied. Previous association studies of candidate genes are summarized in Table 2.

\section{Overview of Previous Candidate Gene Studies}

Several candidate genes have been examined in independent cohorts of the same or different ethnicity, however most of the results were conflicting (Table 2). Most of the previous studies have been carried out with a single small cohort of KD patients and findings were reported without validation in additional case-control sets. This step of confirmation is crucial to rule out type I error (false positive). Population stratification in the first association report also can result in irreproducible results. Correction for multiple comparisons, which is essential for genome-wide approach described in the following paragraph, has to be conducted also in candidate gene studies. Recruiting sufficient number of the patients is indispensable not only to reduce false-negative conclusions but also to obtain association, which remains significant after correction. Compared with the other common diseases in the adults, there are difficulties in collecting DNA samples from young patients. Methods to extract genomic DNA from specimens other than blood (mouthwash, saliva, hairs, and nail clippings) and a multicenter collaboration that allows us to increase size of the cohorts and to validate the association in multiple sample sets may be beneficial.

Sometimes association is not replicated in different ethnicity even if the initial observation was definitely validated in the cohorts of the same ethnic group. One of the reasons is different relative importance of particular genetic variants in susceptibility of complex diseases between ethnicity. Difference in LD or haplotype structures among ethnicity may also lead conflicting results. Most of the replication studies tend to focus on only one or several variations significant in previous studies. When the initial positive association was indirect observation due to LD between the markers tested and a particular gene or variation, the association would not be detected in a different ethnic group in which the responsible variation is not linked with the same markers. Therefore, researchers of both discovery and replication studies should be careful in selecting variations to test.

\section{Genome-wide Approach}

In contrast to candidate gene approach, which is based on assumption, a strategy for searching disease causing mutations or variations from the whole genome relying only on the positional information is called genome-wide approach. Currently, we and another group are searching for susceptibility genes for KD by this approach predominantly studying Japanese and white KD patients, respectively. In this section, I introduce our recent accomplishments in genome-wide linkage study using microsatellite markers (20) and linkage disequilibrium mapping using SNPs (70).

\section{Linkage Study}

In linkage studies, genetic markers linked to diseases are searched by analyzing transmission patterns of the markers within families of multiple patients. Owing to the short history of $\mathrm{KD}$, there is no large kindred with KD available for linkage analysis. Therefore, we applied ASP method, a kind of nonparametric linkage study suitable for investigating genetic factors of complex diseases. ASP method can be conducted only by analyzing DNA samples of siblings affected (and their healthy parents if possible). We have recruited more than 80 families including sibling cases all over Japan and genotyped about 400 polymorphic microsatellite markers. The lod scores were calculated by estimating numbers of shared alleles identical by descent for each marker loci. As a result, in 10 chromosomal loci (4q35, 5q34, 6q27, 7p15, 8q24, 12q24, 18q23, 19q13.2, Xp22, and Xq27) positive linkage signals (maximum lod score $>1.0$ ) were observed (20). Among these candidate loci, 12q24 region showed the most significant evidence of linkage (maximum lod score $=2.69$ ).

\section{Linkage Disequilibrium Mapping}

Because of limited number of mitosis analyzed in ASP method, the resolution of mapping achieved was relatively low and the responsible genes stand in the crowd of a hundred and several tens of genes around each linkage peak. We tried to narrow down the candidate loci and identify susceptibility genes by LD mapping using SNPs. SNPs distributed in 10-25 Mbp area surrounding the linkage peaks were selected from the database and $94 \mathrm{KD}$ cases and 564 controls were genotyped. To increase the power of screening, patients with a positive family history of KD was chosen by priority. In the systematic SNP screening by case-control association study, 


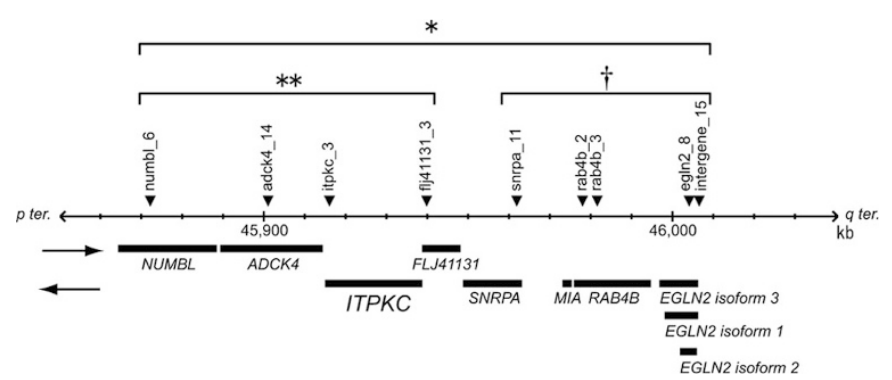

Figure 2. Genes and significant SNPs on the LD block identified in the chromosome 19q13.2 region. Genes oriented $q$ terminus to $p$ terminus are in upper row, with genes in the opposite orientation shown below. Arrowheads indicate the position of SNPs significantly associated with KD. *SNPs associated with KD in Japanese. **SNPs associated with KD both in Japanese and Americans. $†$ SNPs associated with KD in Japanese but not in Americans. Adapted from Onouchi et al. (70) with permission.

we identified an LD block spanning $150 \mathrm{~kb}$ on $19 \mathrm{q} 13.2$ region containing three SNPs significantly associated with KD. Subsequent validation study using different case-control sample sets confirmed the association of the SNPs. Resequencing of the block and subsequent case-control study identified additional six SNPs significantly associated with KD. These candidate SNPs were further screened by transmission disequilibrium test conducted on American multiethnic KD patients-parents trios. Because of difference in LD structure among ethnicity, of the nine significant SNPs, only four centromeric SNPs showed the same trend of association (Fig. 2).

\section{Identification of Inositol 1,4,5-trisphosphate 3-kinase C as a Susceptibility Gene for KD}

Among the four genes in which the significant four SNPs were located, we focused on the known function of ITPKC as a kinase of inositol 1,4,5-trsiphosphate (IP3). IP3 is a second messenger molecule in various types of cells including $\mathrm{T}$ cells, macrophages, and neutrophils involved in the pathogenesis of KD. IP3 transduces signals from cell surface receptors (71) and, in T cells, plays an important role in signal transduction of $\mathrm{Ca}^{2+}$ /nuclear factor of activated T-cells (NFAT) pathway (72-74). Although three isoenzymes of ITPK proteins (ITPKA, ITPKB, and ITPKC) have been known, the relative importance of ITPKC in the immune system was unclear. We investigated mRNA expression of ITPKC in various normal tissues and revealed that ITPKC was greatly induced in PBMCs when activated. Compared with the other isoenzymes, ITPKC was most abundantly expressed in PBMCs and leukemic cell lines and most significantly induced in response to cell stimulation (70). Therefore, we speculated that ITPKC might be related to inflammation. Previous in silico study (75), which has predicted NF-kB binding sequence in the promoter of ITPKC, supported the idea that ITPKC is a potent immune gene.

\section{Negative Regulatory Role of ITPKC in T-cell Receptor Signal Transduction}

Overexpression of ITPKC in Jurkat cells resulted in reduced NFAT activation and $I L-2$ expression. Conversely, knock down of ITPKC by short hairpin RNA enhances NFAT activity and $I L-2$ expression (70). These data indicate that ITPKC acts as a negative regulator of $\mathrm{Ca}^{2+}$ /NFAT pathway in $\mathrm{T}$ cells by modulating the amount of IP3. Through functional analyses of significant SNPs, we clarified that itpkc_3 G/C (rs28493229), a SNP located in intron 1 of ITPKC, reduces mRNA expression of ITPKC in PBMCs down to $70 \%$ by altering splicing efficiency (70). Increased stability of secondary structure of pre-mRNA and reduced binding affinity of some RNA binding proteins related to splicing by the nucleotide change were though to underlie these observations. Reduced ITPKC activity associated with C allele of itpkc_3 may lead enhanced T-cell activation in the pathophysiology of KD. The proposed role of ITPKC and itpkc_3 in $\mathrm{Ca}^{2+} / \mathrm{NFAT}$ pathway in $\mathrm{T}$ cell was demonstrated in Fig. 3. In mice, itpkB (not itpkC) and IP4 play important roles in development of thymocytes and selection and activation of B cells (76-78). Investigation of the role of human ITPKC and biologic significance of itpkc_3 in other immune cells (e.g., macrophages, $\mathrm{B}$ cells, and neutrophils) or nonimmune cells (e.g., endothelial cells and cardiac myocytes) may lead further understanding of the pathogenesis of $\mathrm{KD}$.

\section{Association of itkpc_3 with CAL Formation and IVIG Responsiveness}

As $15 \%$ of KD patients poorly respond to IVIG and these patients are at higher risk for developing CALs, how to predict patients' risk for CALs and responsiveness to IVIG and start additional or alternative therapy before they are destined to develop CALs is the most pressing issue. The $\mathrm{C}$ allele of itpkc_3 was more predominant in patients with CALs and those refractory to IVIG (Table 3, Ref. 70). Considering that these phenotypes somewhat depend on severity of inflammation, our observations may be reasonable. In Japan, experience of treating IVIG resistant KD cases successfully with Cyclosporin A (CsA) is accumulating (unpublished observations). CsA is an immunosuppressant targeting calcineurin that dephosphorylate and lead nuclear translocation of NFAT. Proof of effectiveness of CsA in the treatment of $\mathrm{KD}$ would provide additional support for the importance of $\mathrm{Ca}^{2+} / \mathrm{NFAT}$ pathway activation in the pathogenesis of KD.

There should be genetic variations which directly affects vascular elasticity or anti-inflammatory mechanism of IVIG and increase individual risk for a more severe course when affected with KD. Large-scale association study between KD patients with CAL and those without CAL, as well as between IVIG responders and nonresponders will identify a set of genetic markers efficiently and will contribute in future evidence-based and personalized medicine.

\section{Conclusion}

Completion of human genome project and information of frequencies and LD of the SNPs provided by International HapMap project has made genome-wide approach of investigating genes for complex diseases quite feasible. Genomewide association study (GWAS) with platforms by which 500 thousands to 1 million SNPs can be genotyped at a time has become a mainstream. During the next few years, multiple 

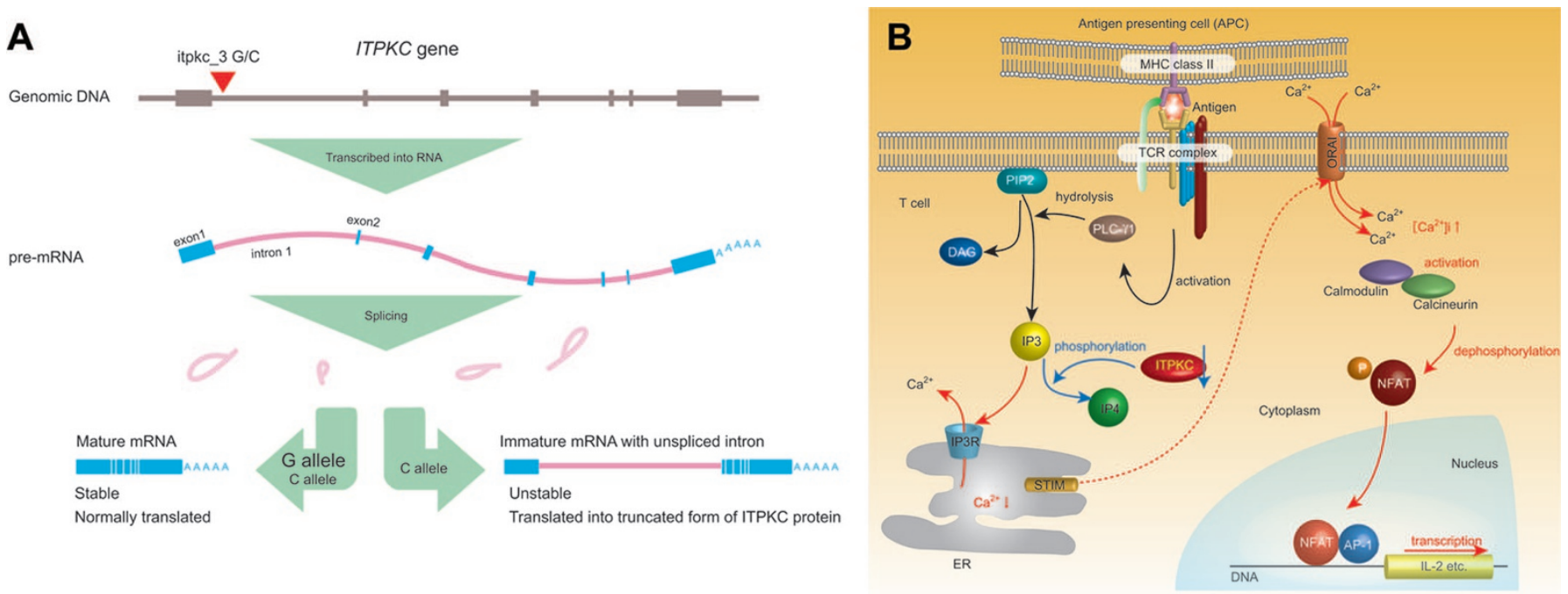

Figure 3. Functional significance of itpkc_3 on ITPKC mRNA and $\mathrm{Ca}^{2+} / \mathrm{NFAT}$ pathway. (A) Effect of itpkc_3 C allele on splicing of ITPKC pre mRNA. The $\mathrm{C}$ allele of itpkc_3 reduces splicing efficiency of IPTKC premRNA. mRNAs harboring unspliced intron 1 cannot be translated properly and will be degraded early by nonsense-mediated decay mechanism. (B) Proposed role of ITPKC as a negative regulator of $\mathrm{Ca}^{2+} / \mathrm{NFAT}$ pathway. When the T-cell receptor (TCR) is bound by antigen/MHC complex on antigen presenting cells (APCs), adaptor molecules and kinases are recruited and phospholipse C- $\gamma 1$ (PLC- $\gamma 1$ ) is activated by phosphorylation of its tyrosine residue. IP3 and diacylglycerol (DAG), another second messenger molecule, are generated by hydrolysis of phosphatidylinositol 3,4-bisphosphate (PIP2) by activated PLC- $\gamma 1$. IP3 binds to its receptor expressed on endoplasmic reticulum (ER) membrane and causes the release of $\mathrm{Ca}^{2+}$ into the cytoplasm. Then depletion of $\mathrm{Ca}^{2+}$ store in ER evokes a process termed as store operated $\mathrm{Ca}^{2+}$ entry in which extracellular $\mathrm{Ca}^{2+}$ enters through calcium release-activated $\mathrm{Ca}^{2+}$ channels on the plasma membrane. Recent advances in research identified the role of stromal interaction molecule (STIM) as a sensor of $\mathrm{Ca}^{2+}$ in ER and ORAI as a calcium release-activated $\mathrm{Ca}^{2+}$ channel. Cytoplasmic $\mathrm{Ca}^{2+}$ binds calmodulin, which in turn activates calcineurin, a calmodulin-dependent phosphatase. Activated calcineurin dephosphorylate NFAT in the cytoplasm and lead nuclear translocation of NFAT. NFAT in the nucleus drives transcription of genes important in T cell activation as a homodimer or heterodimer with other transcription factors. AP1 is one of the transcription partners of NFAT, which is activated by a signal from TCR mediated by DAG (72-74). Reactions and amounts of molecules increased by the effect of itpkc_3 C alleles were represented by red characters and arrows and those reduced by blue, respectively. $\left[\mathrm{Ca}^{2}+\right]$ i: intracellular free $\mathrm{Ca}^{2+}$ concentration.

Table 3. Association between itpkc_3 and KD

\begin{tabular}{|c|c|c|c|c|c|c|c|c|c|}
\hline \multirow[b]{2}{*}{ Samples } & \multicolumn{3}{|c|}{ itpkc_3 genotype } & \multirow[b]{2}{*}{ Total } & \multirow{2}{*}{$\begin{array}{l}\text { arrier ratio of } \\
\mathrm{C} \text { allele }\end{array}$} & \multirow[b]{2}{*}{$\mathrm{OR} *$} & \multirow[b]{2}{*}{$95 \% \mathrm{CI}$} & \multirow[b]{2}{*}{$\chi^{2}$} & \multirow[b]{2}{*}{$p$} \\
\hline & GG & GC & $\mathrm{CC}$ & & & & & & \\
\hline \multicolumn{10}{|l|}{ Japanese } \\
\hline $\mathrm{KD}$ & 376 & 234 & 27 & 637 & $41 \%$ & 1.89 & $1.53-2.33$ & 35.8 & $2.2 \times 10^{-9}$ \\
\hline KD with CAL $\dagger$ & 61 & 44 & 2 & 107 & $43 \%$ & 2.05 & $1.37-3.08$ & 12.4 & 0.00044 \\
\hline $\mathrm{KD}$ without $\mathrm{CAL} \dagger$ & 172 & 94 & 12 & 278 & $38 \%$ & 1.68 & $1.27-2.21$ & 13.4 & 0.00025 \\
\hline Control & 756 & 249 & 29 & 1034 & $27 \%$ & & & & \\
\hline Samples & \multicolumn{3}{|c|}{ Transmitted $\mathrm{C}$ allele } & \multicolumn{2}{|c|}{ Untransmitted $\mathrm{C}$ allele } & OR & $95 \% \mathrm{CI}$ & $\chi^{2}$ & $p$ \\
\hline \multicolumn{10}{|l|}{ US $\ddagger$} \\
\hline $\mathrm{KD}$ & \multicolumn{3}{|c|}{64} & \multicolumn{2}{|c|}{30} & 2.13 & $1.38-3.29$ & 12.3 & 0.00045 \\
\hline KD with CAL & \multicolumn{3}{|c|}{37} & \multicolumn{2}{|c|}{11} & 3.36 & $1.72-6.59$ & 14.1 & 0.00018 \\
\hline KD without CAL & \multicolumn{3}{|c|}{27} & \multicolumn{2}{|c|}{18} & 1.50 & $0.63-2.72$ & 1.8 & 0.18 \\
\hline KD IVIG non responder & \multicolumn{3}{|c|}{14} & \multicolumn{2}{|c|}{3} & 4.67 & $1.34-16.24$ & 7.1 & 0.0076 \\
\hline KD IVIG responder & \multicolumn{3}{|c|}{39} & \multicolumn{2}{|c|}{22} & 1.77 & $1.05-2.99$ & 4.7 & 0.030 \\
\hline
\end{tabular}

*Association study of genotype frequencies in dominant model of inheritance (GG vs. GC+CC).

$\dagger$ Samples without clinical information were excluded from analysis.

\$Transmission disequilibrium test of 209 triads of multiethnic KD patients and their parents.

Adapted from Onouchi et al. (70) with permission.

susceptibility genes may be identified from such large-scale studies. We can also hope that new insight in the pathophysiology of KD may be derived from the findings in hypothesisfree genetic research. Abovementioned genome resources may also contribute to candidate gene approach. Selecting tag SNPs that represent haplotypes by the information of LD may facilitate an efficient and quality screening of candidate genes. Pathways and molecular networks in which susceptibility genes identified in genome-wide approach are involved will expand the search range of candidate genes. It is suggestive that association of the SNPs in some downstream genes of NFAT (TNF- $\alpha, C D 40 L$, and $I L-4)$ with KD and/or outcome has been reported.

Although much remains to be done, it is hoped that both genetic approaches will complement one another in clarifying the genetic background of $\mathrm{KD}$, open the door to elucidation of the etiology, and allow for establishment of new therapeutic and preventive strategies. 


\section{REFERENCES}

1. Kawasaki T 1967 Acute febrile mucocutaneous syndrome with lymphoid involvement with specific desquamation of the fingers and toes in children. Arerugi $16: 178-222$

2. Burns JC 2002 Commentary: translation of Dr. Tomisaku Kawasaki's original report of fifty patients in 1967. Pediatr Infect Dis J 21:993-995

3. Kato H, Koike S, Yamamoto M, Ito Y, Yano E 1975 Coronary aneurysms in infants and young children with acute febrile mucocutaneous lymph node syndrome. J Pediatr 86:892-898

4. Nakamura Y, Yashiro M, Uehara R, Oki I, Watanabe M, Yanagawa H 2008 Epidemiologic features of Kawasaki disease in Japan: results from the nationwide survey in 2005-2006. J Epidemiol 18:167-172

5. Holman RC, Curns AT, Belay ED, Steiner CA, Effler PV, Yorita KL, Miyamura J, Forbes S, Schonberger LB, Melish M 2005 Kawasaki syndrome in Hawaii. Pediatr Infect Dis J 24:429-433

6. Fujita Y, Nakamura Y, Sakata K, Hara N, Kobayashi M, Nagai M, Yanagawa H, Kawasaki T 1989 Kawasaki disease in families. Pediatrics 84:666-669

7. Uehara R, Yashiro M, Nakamura Y, Yanagawa H 2003 Kawasaki disease in parents and children. Acta Paediatr 92:694-697

8. Matsuda I, Hattori S, Nagata N, Fruse A, Nambu H 1977 HLA antigens in mucocutaneous lymph node syndrome. Am J Dis Child 131:1417-1418

9. Kato S, Kimura M, Tsuji K, Kusakawa S, Asai T, Juji T, Kawasaki T 1978 HLA antigens in Kawasaki disease. Pediatrics 61:252-255

10. Krensky AM, Berenberg W, Shanley K, Yunis EJ 1981 HLA antigens in mucocutaneous lymph node syndrome in New England. Pediatrics 67:741-743

11. Krensky AM, Grady S, Shanley KM, Berenberg W, Yunis EJ 1983 Epidemic and endemic HLA-B and DR associations in mucocutaneous lymph node syndrome. Hum Immunol 6:75-77

12. Keren G, Danon YL, Orgad S, Kalt R, Gazit E 1982 HLA Bw51 is increased in mucocutaneous lymph node syndrome in Israeli patients. Tissue Antigens 20:144146

13. Chang CC, Hawkins BR, Kao HK, Chow CB, Lau YL 1992 Human leucocyte antigens in southern Chinese with Kawasaki disease. Eur J Pediatr 151:866

14. Oh JH, Han JW, Lee SJ, Lee KY, Suh BK, Koh DK, Lee JS, Oh CK, Kim TG, Choi HB 2008 Polymorphisms of human leukocyte antigen genes in Korean children with Kawasaki disease. Pediatr Cardiol 29:402-408

15. Kaslow RA, Bailowitz A, Lin FY, Koslowe P, Simonis T, Israel E 1985 Association of epidemic Kawasaki syndrome with the HLA-A2, B44, Cw5 antigen combination. Arthritis Rheum 28:938-940

16. Harada F, Sada M, Kamiya T, Yanase Y, Kawasaki T, Sasazuki T 1986 Genetic analysis of Kawasaki syndrome. Am J Hum Genet 39:537-539

17. Barron KS, Silverman ED, Gonzales JC, St Clair M, Anderson K, Reveille JD 1992 Major histocompatibility complex class II alleles in Kawasaki syndrome-lack of consistent correlation with disease or cardiac involvement. J Rheumatol 19:17901793

18. Huang FY, Chang TY, Chen MR, Hsu CH, Lee HC, Lin SP, Kao HA, Chiu NC, Chi H, Liu TY, Liu HF, Dang CW, Chu CC, Lin M, Sung TC, Lee YJ 2007 Genetic variations of HLA-DRB1 and susceptibility to Kawasaki disease in Taiwanese children. Hum Immunol 68:69-74

19. Fildes N, Burns JC, Newburger JW, Klitz W, Begovich AB 1992 The HLA class II region and susceptibility to Kawasaki disease. Tissue Antigens 39:99-101

20. Onouchi Y, Tamari M, Takahashi A, Tsunoda T, Yashiro M, Nakamura Y, Yanagawa H, Wakui K, Fukushima Y, Kawasaki T, Nakamura Y, Hata A 2007 A genomewide linkage analysis of Kawasaki disease: evidence for linkage to chromosome 12. J Hum Genet 52:179-190

21. Maury CP, Salo E, Pelkonen P 1989 Elevated circulating tumor necrosis factor-alpha in patients with Kawasaki disease. J Lab Clin Med 113:651-654

22. Matsubara T, Furukawa S, Yabuta K 1990 Serum levels of tumor necrosis factor, interleukin 2 receptor, and interferon-gamma in Kawasaki disease involved coronary-artery lesions. Clin Immunol Immunopathol 56:29-36

23. Weiss JE, Eberhard BA, Chowdhury D, Gottlieb BS 2004 Infliximab as a novel therapy for refractory Kawasaki disease. J Rheumatol 31:808-810

24. Burns JC, Mason WH, Hauger SB, Janai H, Bastian JF, Wohrley JD, Balfour I, Shen CA, Michel ED, Shulman ST, Melish ME 2005 Infliximab treatment for refractory Kawasaki syndrome. J Pediatr 146:662-667

25. Saji T, Kemmotsu Y 2006 Infliximab for Kawasaki syndrome. J Pediatr 149:426

26. Kamizono S, Yamada A, Higuchi T, Kato H, Itoh K 1999 Analysis of tumor necrosis factor-alpha production and polymorphisms of the tumor necrosis factor-alpha gene in individuals with a history of Kawasaki disease. Pediatr Int 41:341-345

27. Quasney MW, Bronstein DE, Cantor RM, Zhang Q, Stroupe C, Shike H, Bastian JF, Matsubara T, Fujiwara M, Akimoto K, Newburger JW, Burns JC 2001 Increased frequency of alleles associated with elevated tumor necrosis factor-alpha levels in children with Kawasaki disease. Pediatr Res 49:686-690

28. Chien YH, Chang KW, Yang YH, Lu MY, Lin YT, Chiang BL 2003 Association between levels of TNF-alpha and TNF-alpha promoter -308 A/A polymorphism in children with Kawasaki disease. J Formos Med Assoc 102:147-150

29. Ahn SY, Jang GC, Shin JS, Shin KM, Kim DS 2003 Tumor necrosis factor-alpha levels and promoter polymorphism in patients with Kawasaki disease in Korea. Yonsei Med J 44:1021-1026

30. Cheung YF, Huang GY, Chen SB, Liu XQ, Xi L, Liang XC, Huang MR, Chen S, Huang LS, Liu XQ, Chan KW, Lau YL 2008 Inflammatory gene polymorphisms and susceptibility to Kawasaki disease and its arterial sequelae. Pediatrics 122:e608e614

31. Burns JC, Shimizu C, Shike H, Newburger JW, Sundel RP, Baker AL, Matsubara T, Ishikawa Y, Brophy VA, Cheng S, Grow MA, Steiner LL, Kono N, Cantor RM 2005
Family-based association analysis implicates IL-4 in susceptibility to Kawasaki disease. Genes Immun 6:438-444

32. Wu SF, Chang JS, Wan L, Tsai CH, Tsai FJ 2005 Association of IL-1Ra gene polymorphism, but no association of IL-1beta and IL-4 gene polymorphisms, with Kawasaki disease. J Clin Lab Anal 19:99-102

33. Huang FY, Chang TY, Chen MR, Lee HC, Chiu NC, Chi H, Hsu CH, Lin SP, Liu $\mathrm{HF}$, Chen WF, Chu CC, Lin M, Lee YJ 2008 The $-590 \mathrm{C} / \mathrm{T}$ and $8375 \mathrm{~A} / \mathrm{G}$ interleukin-4 polymorphisms are not associated with Kawasaki disease in Taiwanese children. Hum Immunol 69:52-57

34. Jibiki T, Terai M, Shima M, Ogawa A, Hamada H, Kanazawa M, Yamamoto S, Oana S, Kohno Y 2001 Monocyte chemoattractant protein 1 gene regulatory region polymorphism and serum levels of monocyte chemoattractant protein 1 in Japanese patients with Kawasaki disease. Arthritis Rheum 44:2211-2212

35. Burns JC, Shimizu C, Gonzalez E, Kulkarni H, Patel S, Shike H, Sundel RS, Newburger JW, Ahuja SK 2005 Genetic variations in the receptor-ligand pair CCR5 and CCL3L1 are important determinants of susceptibility to Kawasaki disease. J Infect Dis 192:344-349

36. Sohn MH, Hur MW, Kim DS 2001 Interleukin 6 gene promoter polymorphism is not associated with Kawasaki disease. Genes Immun 2:357-362

37. Jin HS, Kim HB, Kim BS, Lee JK, Seo EJ, Yoo HW, Park IS, Hong YM, Hong SJ 2007 The IL-10 (-627 A/C) promoter polymorphism may be associated with coronary aneurysms and low serum albumin in Korean children with Kawasaki disease. Pediatr Res 61:584-587

38. Hsueh KC, Lin YJ, Chang JS, Wan L, Tsai YH, Tsai CH, Chen CP, Tsai FJ 2008 Influence of interleukin 18 promoter polymorphisms in susceptibility to Kawasaki disease in Taiwan. J Rheumatol 35:1408-1413

39. Jhang WK, Kang MJ, Jin HS, Yu J, Kim BJ, Kim BS, Lee JK, Seo EJ, Yoo HW, Park IS, Hong YM, Hong SJ 2009 The CCR5 (-2135C/T) polymorphism may be associated with the development of Kawasaki disease in Korean Children. J Clin Immunol 29:22-28

40. Breunis WB, Biezeveld MH, Geissler J, Kuipers IM, Lam J, Ottenkamp J, Hutchinson A, Welch R, Chanock SJ, Kuijpers TW 2007 Polymorphisms in chemokine receptor genes and susceptibility to Kawasaki disease. Clin Exp Immunol 150:83-90

41. Ferrara N 2003 The biology of VEGF and its receptors. Nat Med 9:669-676

42. Ohno T, Igarashi H, Inoue K, Akazawa K, Joho K, Hara T 2000 Serum vascular endothelial growth factor: a new predictive indicator for the occurrence of coronary artery lesions in Kawasaki disease. Eur J Pediatr 159:424-429

43. Kariyazono H, Ohno T, Khajoee V, Ihara K, Kusuhara K, Kinukawa N, Mizuno Y, Hara T 2004 Association of vascular endothelial growth factor (VEGF) and VEGF receptor gene polymorphisms with coronary artery lesions of Kawasaki disease. Pediatr Res 56:953-959

44. Breunis WB, Biezeveld MH, Geissler J, Ottenkamp J, Kuipers IM, Lam J, Hutchinson A, Welch R, Chanock SJ, Kuijpers TW 2006 Vascular endothelial growth factor gene haplotypes in Kawasaki disease. Arthritis Rheum 54:1588-1594

45. Hsueh KC, Lin YJ, Chang JS, Wan L, Tsai YH, Tsai CH, Chen CP, Tsai FJ 2008 Association of vascular endothelial growth factor C-634 g polymorphism in Taiwanese children with Kawasaki disease. Pediatr Cardiol 29:292-296

46. Huang FY, Chang TY, Chen MR, Lee HC, Chi H, Chiu NC, Hsu CH, Lin SP, Kao HA, Chen WF, Chan HW, Liu HF, Chu CC, Lin M, Lee YJ 2008 Lack of association of the vascular endothelial growth factor gene polymorphisms with Kawasaki disease in Taiwanese children. J Clin Immunol 28:322-328

47. Takeuchi K, Yamamoto K, Kataoka S, Kakihara T, Tanaka A, Sato S, Uchiyama M 1997 High incidence of angiotensin I converting enzyme genotype II in Kawasaki disease patients with coronary aneurysm. Eur J Pediatr 156:266-268

48. Wu SF, Chang JS, Peng CT, Shi YR, Tsai FJ 2004 Polymorphism of angiotensin-1 converting enzyme gene and Kawasaki disease. Pediatr Cardiol 25:529-533

49. Shim YH, Kim HS, Sohn S, Hong YM 2006 Insertion/deletion polymorphism of angiotensin converting enzyme gene in Kawasaki disease. J Korean Med Sci 21:208-211

50. Fukazawa R, Sonobe T, Hamamoto K, Hamaoka K, Sakata K, Asano T, Imai T, Kamisago M, Ohkubo T, Uchikoba Y, Ikegami E, Watanabe M, Ogawa S 2004 Possible synergic effect of angiotensin-I converting enzyme gene insertion/deletion polymorphism and angiotensin-II type-1 receptor $1166 \mathrm{~A} / \mathrm{C}$ gene polymorphism on ischemic heart disease in patients with Kawasaki disease. Pediatr Res 56:597-601

51. Senzaki H, Masutani S, Kobayashi J, Kobayashi T, Nakano H, Nagasaka H, Sasaki N, Asano H, Kyo S, Yokote Y 2001 Circulating matrix metalloproteinases and their inhibitors in patients with Kawasaki disease. Circulation 104:860-863

52. Furuno K, Takada H, Yamamoto K, Ikeda K, Ohno T, Khajoee V, Mizuno Y, Hara T 2007 Tissue inhibitor of metalloproteinase 2 and coronary artery lesions in Kawasaki disease. J Pediatr 151:155-160

53. Park JA, Shin KS, Kim YW 2005 Polymorphism of matrix metalloproteinase-3 promoter gene as a risk factor for coronary artery lesions in Kawasaki disease. J Korean Med Sci 20:607-611

54. Ikeda K, Ihara K, Yamaguchi K, Muneuchi J, Ohno T, Mizuno Y, Hara T 2008 Genetic analysis of MMP gene polymorphisms in patients with Kawasaki disease. Pediatr Res 63:182-185

55. Hong YM, Jin HS, Park IS, Hong SJ 2008 Association of the matrix metalloproteinase-3 $(-439 \mathrm{C} / \mathrm{G})$ promoter polymorphism with Kawasaki disease in Korean children. Heart Vessels 23:341-347

56. Nishimura S, Zaitsu M, Hara M, Yokota G, Watanabe M, Ueda Y, Imayoshi M, Ishii E, Tasaki H, Hamasaki Y 2003 A polymorphism in the promoter of the CD14 gene (CD14/-159) is associated with the development of coronary artery lesions in patients with Kawasaki disease. J Pediatr 143:357-362

57. Biezeveld MH, Kuipers IM, Geissler J, Lam J, Ottenkamp JJ, Hack CE, Kuijpers TW 2003 Association of mannose-binding lectin genotype with cardiovascular abnormalities in Kawasaki disease. Lancet 361:1268-1270 
58. Biezeveld MH, Geissler J, Weverling GJ, Kuipers IM, Lam J, Ottenkamp J, Kuijpers TW 2006 Polymorphisms in the mannose-binding lectin gene as determinants of age-defined risk of coronary artery lesions in Kawasaki disease. Arthritis Rheum 54:369-376

59. Cheung YF, Ho MH, Ip WK, Fok SF, Yung TC, Lau YL 2004 Modulating effects of mannose binding lectin genotype on arterial stiffness in children after Kawasaki disease. Pediatr Res 56:591-596

60. Ouchi K, Suzuki Y, Shirakawa T, Kishi F 2003 Polymorphism of SLC11A1 (formerly NRAMP1) gene confers susceptibility to Kawasaki disease. J Infect Dis $187: 326-329$

61. Tsukahara H, Hiraoka M, Saito M, Nishida K, Kobata R, Tsuchida S, Toyooka M, Kimura H, Gejyo F, Mayumi M 2000 Methylenetetrahydrofolate reductase polymorphism in Kawasaki disease. Pediatr Int 42:236-240

62. Taniuchi S, Masuda M, Teraguchi M, Ikemoto Y, Komiyama Y, Takahashi H, Kino M, Kobayashi Y 2005 Polymorphism of Fc gamma RIIa may affect the efficacy of gamma-globulin therapy in Kawasaki disease. J Clin Immunol 25:309-313

63. Biezeveld M, Geissler J, Merkus M, Kuipers IM, Ottenkamp J, Kuijpers T 2007 The involvement of $\mathrm{Fc}$ gamma receptor gene polymorphisms in Kawasaki disease. Clin Exp Immunol 147:106-111

64. Kanai M, Tanabe S, Okada M, Suzuki H, Niki T, Katsuura M, Akiba T, Hayasaka K 2003 Polymorphisms of heme oxygenase-1 and bilirubin UDP-glucuronosyltransferase genes are not associated with Kawasaki disease susceptibility. Tohoku J Exp Med 200:155-159

65. Huang Y, Lee YJ, Chen MR, Hsu CH, Lin SP, Sung TC, Chang SC, Chang JG 2000 Polymorphism of transmembrane region of MICA gene and Kawasaki disease. Exp Clin Immunogenet 17:130-137

66. Minami T, Suzuki H, Takeuchi T, Uemura S, Sugatani J, Yoshikawa N 2005 A polymorphism in plasma platelet-activating factor acetylhydrolase is involved in resistance to immunoglobulin treatment in Kawasaki disease. J Pediatr 147:78-83

67. Khajoee V, Kariyazono H, Ohno T, Ihara K, Mizuno Y, Kusuhara K, Hara T 2003 Inducible and endothelial constitutive nitric oxide synthase gene polymorphisms in Kawasaki disease. Pediatr Int 45:130-134
68. Onouchi Y, Onoue S, Tamari M, Wakui K, Fukushima Y, Yashiro M, Nakamura Y, Yanagawa H, Kishi F, Ouchi K, Terai M, Hamamoto K, Kudo F, Aotsuka H, Sato Y, Nariai A, Kaburagi Y, Miura M, Saji T, Kawasaki T, Nakamura Y, Hata A 2004 CD40 ligand gene and Kawasaki disease. Eur J Hum Genet 12:1062-1068

69. Huang FY, Chang TY, Chen MR, Chiu NC, Chi H, Lee HC, Lin SP, Chen CK, Chan HW, Chen WF, Liu HF, Chu CC, Lin M, Lee YJ 2008 Genetic polymorphisms in the CD40 ligand gene and Kawasaki disease. J Clin Immunol 28:405-410

70. Onouchi Y, Gunji T, Burns JC, Shimizu C, Newburger JW, Yashiro M, Nakamura Y, Yanagawa H, Wakui K, Fukushima Y, Kishi F, Hamamoto K, Terai M, Sato Y, Ouchi K, Saji T, Nariai A, Kaburagi Y, Yoshikawa T, Suzuki K, Tanaka T, Nagai T, Cho H, Fujino A, Sekine A, Nakamichi R, Tsunoda T, Kawasaki T, Nakamura Y, Hata A 2008 ITPKC functional polymorphism associated with Kawasaki disease susceptibility and formation of coronary artery aneurysms. Nat Genet 40:35-42

71. Berridge MJ, Irvine RF 1989 Inositol phosphates and cell signalling. Nature 341:197-205

72. Rao A, Luo C, Hogan PG 1997 Transcription factors of the NFAT family: regulation and function. Annu Rev Immunol 15:707-747

73. Crabtree GR, Olson EN 2002 NFAT signaling: choreographing the social lives of cells. Cell 109:S67-S79

74. Macian F 2005 NFAT proteins: key regulators of T-cell development and function. Nat Rev Immunol 5:472-484

75. Liu R, McEachin RC, States DJ 2003 Computationally identifying novel NF-kappa B-regulated immune genes in the human genome. Genome Res 13:654-661

76. Pouillon V, Hascakova-Bartova R, Pajak B, Adam E, Bex F, Dewaste V, Van Lint C, Leo O, Erneux C, Schurmans S 2003 Inositol 1,3,4,5-tetrakisphosphate is essential for T lymphocyte development. Nat Immunol 4:1136-1143

77. Miller AT, Sandberg M, Huang YH, Young M, Sutton S, Sauer K, Cooke MP 2007 Production of Ins $(1,3,4,5) \mathrm{P} 4$ mediated by the kinase Itpkb inhibits store-operated calcium channels and regulates $B$ cell selection and activation. Nat Immunol $8: 514-521$

78. Huang YH, Grasis JA, Miller AT, Xu R, Soonthornvacharin S, Andreotti AH, Tsoukas CD, Cooke MP, Sauer K 2007 Positive regulation of Itk PH domain function by soluble IP4. Science 316:886-889 